\title{
Politics of Strata
}

Nigel Clark

Theory, Culture \& Society

Forthcoming 2017 Special Issue: Geosocial Formations and the Anthropocene

Modern western political thought revolves around globality, focusing on the partitioning and the connecting up of the earth's surface. But climate change and the Anthropocene thesis raise pressing questions about human interchange with the geological and temporal depths of the earth. Drawing on contemporary earth science and the geophilosophy of Deleuze and Guattari, this article explores how geological strata are emerging as provocations for political issue formation. The first section reviews the emergence - and eventual turn away from - concern with `revolutions of the earth' during the $18-19^{\text {th }} \mathrm{C}$ discovery of 'geohistory'. The second section looks at the subterranean world both as an object of 'downward' looking territorial imperatives and as the ultimate power source of all socio-political life. The third section weighs up the prospects of 'earth system governance'. The paper rounds up with some general thoughts about the possibilities of 'negotiating strata' in more generative and judicious ways.

\section{Keywords}

geopolitics, Deleuze and Guattari, Anthropocene, earth system governance, vertical territory, earth science, geohistory

\section{When am I?}

“Where do I belong?" seems to be the question that plagues so many of the discussions I participate in', muses Irit Rogoff early in the book Terra Infirma. 'As a constant lament it refers to dislocations felt by displaced subjects towards disrupted histories and to shifting and transient national identities' (2000: 14). My own ancestors dislocated themselves, 
though I have not a lot to lament. During my childhood, the islands in the southwest Pacific where I lived had a per capita GDP that was among the highest in the world. Based on agricultural exports, this economic prosperity funded a robust welfare state, including universal free education. In the process it provided me with an abundance of opportunities.

Any credible account of my country's trajectory would include European voyages of discovery, trans-global entrepreneurialism and violent appropriation of land from its Polynesian occupants. A central narrative thread would be the transplanting of European-style agro-ecosystems and the development of an export economy facilitated by maritime networks centred on Great Britain. Such a history, in short, positions a single nation state in the greater story of intensifying but uneven processes of encounter, connection and circulation characteristically referred to as globalization.

But there is another way this story could be told. In this other telling, it would matter profoundly that the agricultural regime in question originated in the fertile, recently glaciated lands of northwestern Europe. As it would matter that the distant region onto which this regime was grafted had soils low in the micronutrients essential to sustaining a pastoral ecosystem (Cushman, 2013: 129-131). The crux of this narrative would also entail a kind of interconnectivity. Behind escalating agricultural revenue was the conversion of large areas of previously marginal and erosion-prone hill country into fertile grassland suitable for raising livestock. This took place through the fusion of two distinct technologies: application of artificial fertilizer and powered flight.

Successful trials and rollout of aerial top-dressing in New Zealand in the 1940s took advantage of pilots trained during World War 2 and surplus military aircraft. Intensive air-born application of superphosphates - agrochemical fertilizer high in phosphorous and nitrogen - lead to remarkable gains in productivity - a 'grasslands revolution' that 
soon spread to southeastern Australia (Cushman, 2013: 129-131). The key to the innovation of aerial top-dressing, for my purposes, is that it is as much an assemblage in geological time as in geographical space. Fueling regular flights over extensive areas called for cheap hydrocarbons. These were imported from vast Middle Eastern oil fields whose origin lay in the sedimentation of organic matter during the Jurassic and Cretaceous periods. And it required huge amounts of affordable phosphate - sourced from the tiny southwest Pacific islands of Nauru and Banaba where it had been deposited over millions of years in the form of the droppings of seabirds that fed off ocean upwellings flush with marine life. On the back of mining these 'phosphate colonies' almost out of existence, New Zealand and Australia environmentally engineered millions of hectares into lucrative export-oriented agro-ecosystems (Cushman, 2013: 129-135).

In this way, the conditions of economic prosperity in which I was raised were to a significant degree an effect of cutting into and combining very different geological strata into a novel assemblage. My autobiography, in this sense, might be seen also as a kind of stratobiography: a story composed out of traversals of the deep, sedimented time of the earth itself. And for this the apposite question might be not only where but when do I belong?

Elements of this story - appropriations of ancestral Maori land, of the very earth of Pacific Islands, and of the resources beneath the feet of Middle Eastern communities have involved intense political contestation. Today, however, the geological strata in my narrative are 'becoming political’ in different ways. At the 2015 UN Climate Change Conference in Paris, representatives of 195 nation states agreed in principle that the prevention of dangerous climate change requires $80 \%$ of known reserves of fossil hydrocarbons to remain in the ground. At the same time, research teams have identified human interference in global nitrogen and phosphorous cycles - largely the result of 
fertilizer application - as one of the most serious threats to the functioning of the earth system (Rockström et al, 2009; Steffen et al, 2015). So profound is the impact of agrochemical fertilizer, researchers suggest, we would need to go back some 2.5 billion years to find changes in the global nitrogen cycle of comparable magnitude (Lewis and Maslin, 2015: 172).

Readers of Gilles Deleuze and Félix Guattari will have picked up the inspiration behind the idea that a fertilizer-spreading plane is an assemblage that brings together the productions of distinct geological strata. 'The assemblage', announce Deleuze and Guattari in A Thousand Plateaus, is between two layers, two strata’ (1987:40, see also DeLanda, 1997: 59-66). In order to understand the world in both its reality and its potentiality, they insist, it is vital that no conceivable category or class of things should be prioritized over any other. But the premise of ontological 'flatness’ - with its affirmation of the possibility of disparate entities entering into unforeseeable conjunctions recognizes that the actually existing universe is profoundly layered and structured (see DeLanda, 2002: 47). All kinds of free-flowing matter-energy, according to Deleuze and Guattari, have tendencies to settle into bands or layers with a certain self-consistency. It is this organizational layering that enables composite things to come into being - things that are novel precisely because they have emerged out of the traversal and combining of different strata (1987: 40-49; 335-7). While rejecting any simple unidirectional or teleological relationship between one stratum and the next, Deleuze and Guattari broadly accept that an earlier stratum offers the conditions of possibility for new categories of things and for later strata, proposing 'a coded system of stratification' made up of 'hierarchies of order between groupings; and, holding it all together in depth, a succession of framing forms, each of which informs a substance and in turn serves as a substance for another form' (1987: 335). 
In the Deleuzoguattarian universe, any manifestation of matter-energy, not just the rocky stuff of the earth, can bed down into strata. But the earth - this actual planet - does have special significance. Where fellow continental philosophers have often taken the earth to be the stable ground or platform of all human experience, Deleuze and Guattari keep coming back to the idea that our planet pulses with the possibility of destratification, new combinational possibilities, reorganization (1994: 85; 1987: 40). And in this regard all human life - all life in general - plays upon the potentiality of the stratifying-destratifying earth. Drawing on Fernand Braudel's notion of the very longue durée, Deleuze and Guattari venture that all `history is a geo-history’ (1994: 95).

In a formulation Deleuze and Guattari would have appreciated, stratigrapher Jan Zalasiewicz describes the earth as 'a gigantic machine for producing strata' (2008: 17). Zalasiewicz - also chair of the Anthropocene working group - impresses upon us that our planet is unique in the solar system for the diversity, elaborateness, and 'superabundance' of its stratal composition. This stratigraphic richness results from the exceptional mobility of the earth's crust, driven by great churning currents of magma in the inner earth and ultimately powered by the radioactivity of the planet's core. But the incessant deformation and reformation of the planet's rocky crust is also an expression of the erosive effects of powerful circulation systems in the envelope of the earth's air and water - propelled by incoming solar energy (Zalasiewicz 2008: 14-5).

As the Anthropocene thesis proposes, human activities now intervene substantially in these circulation systems - to the extent that we are likely to leave a pronounced imprint on the geological stratum currently in formation (Zalasiewicz et al, 2008). While it is the claim that humans have become geophysical agents that is attracting wide attention, what may be of more enduring significance is the way Anthropocene science is merging inquiry into the stratal composition of the planet's crust with the study of the interacting components of the earth system (see Zalasiewicz et al, 2016). It is this synthesis of older 
traditions of stratigraphic geology with newer earth systems thinking - aided by new techniques for calibrating the chemical composition of the atmosphere and the other earth subsystems - that makes it possible to anticipate the lasting imprint of current human actions on the lithic structure of the upper earth.

This integrated approach underpins new understandings of the way variability in the conditions at the earth's surface - in the envelope that includes all living things - is systematically connected with strata-forming processes. As geoscientists observe: 'detailed paleo-records show that the Earth is never static and it is almost impossible to define an equilibrium state; variability abounds at nearly all spatial and temporal scales' (Steffen et al, 2004: 295). In other words, it is by analyzing the differentiated composition of the layers that make up the earth's crust - the more-or-less vertical 'stratigraphic column’ - that scientists are piecing together the long, eventful history of the 'coupled' subsystems of the atmosphere, hydrosphere, biosphere and lithosphere. A story that has emerged in recent decades is that transitions in the overall earth system can be surprisingly abrupt - with climate and other entangled subsystems shifting their entire operating state in timescales briefer than a human lifetime. It is this threshold transition scenario - evoked in the context of human-induced climate change - that led the way to earth system dynamics being framed as a political problem, quickly followed by similar problematization of other earth subsystems. What characterizes these emergent political issues, I suggest, is that connections are being made - with varying degrees of explicitness - between human interaction with geological strata (prospecting, extraction, disposal, contamination) and the functioning of ecological and earth systems. And it is in this sense, I propose, that we might talk about - in not-quite-adequate shorthand - a politics of strata.

In this paper, I move between social and political theory, philosophy, and earth science to explore some of the ways that strata are emerging as sites of political issue formation. 
Following the geophilosophy of Deleuze and Guattari, I contend that all dynamical processes - human, nonhuman, organic, inorganic - generate distinct strata, though my concern here is with the more conventionally geological concept of strata as the compositional layers of the earth's crust. Rather than simply affirming that climate change or the Anthropocene thesis has suddenly propelled geological strata into political significance, I suggest that the stratified composition of the earth's crust - and its traversals and negotiations - has long played a constitutive role in social and political formations. And indeed, that all social and political formations are implicated with specific geological formations.

But I also want to ask how and why modern western political discourses have come to focus overwhelmingly on the organization of the surface of the earth rather than on its layering or multi-dimensionality. Or to put it another way, why `the discovered, interconnected and singularized earth' (Sloterdijk, 2013: 5) - now prevails over a planet of hidden depths, potentiality and multiplicity. And I'm interested in what can be learnt from a long-term perspective on the earth's structure and dynamism that might help us reimagine the political for times of accelerating geophysical change.

To set out, I want to give a sense of the historical longevity of 'stratal' issues by turning briefly to a formative moment in the long stratobiography of the contemporary world. In his geneaological analysis of modern modes and techniques of political ordering, Stuart Elden poses the question 'Where did (the) idea of exclusive ownership of a portion of the earth's surface come from?' Elden tracks the birth of territory all the way back to the 'geo-metricians' of ancient river valley farming communities: the surveyors who retraced the borders of fields each time waters withdrew from the floodplains (2013a: 2-3; 2013b: 49). Michel Serres too proposes that it is from this apportioning of annually deposited alluvium that `politics and laws were born' (1995: 53). What is intriguing about these originary stories of the territorial impulse, I would suggest, is that 
the assertion of propriety over the earth's surface is inextricable from physical processes that are fundamental to the vertical layering of the planet's crust. In the oldest and most primordial storyline we can conjure up, territory emerges dripping from the watery dynamics of sedimentary geology.

We might also recall that coeval with this incipient 'geometry', peoples of adjacent highlands were beginning to engage with the resources of the earth in a very different way. It was in the semi-arid plateaus of the Middle East that artisans first learned to mine the earth for its ores, to smelt and work metals. They took their products, and later their skills, down from the metalliferous highlands to the alluvial plains - where a burgeoning agricultural surplus was furnishing new desires and means (Aitchison, 1960: 18). Deleuze and Guattari, enthusiastic students of archaeometallurgical scholarship, make much of this meeting between peoples who till the earth's fertile surface and those who probe its metallogenic subsurface. Metalworkers who 'follow the matter-flow of the subsoil' were (and are) largely itinerant, they contend, preferring to construct unbounded political spaces that morph and shift in response to dynamic physical processes (1987: 412). Agrarian communities, by contrast, were sedentary, bound by rules of land ownership and strict control of the agricultural surplus. And this fundamental difference means their co-existence is rife with tension (1987: 410-415).

However speculative their anthropology may be, the point Deleuze and Guattari make is that political issues arise not only or primarily out of socio-cultural or ideological differences, but out of different ways of inhabiting the very stuff of the earth. Which is to say that as far back as our histories can reach, we find peoples who have come into being through their expression of the various potentialities of the earth: each drawing out and elaborating upon the material-energetic possibilities of the geological strata they inhabit. And in this way, we get an intimation that if all 'history is a geo-history' then sooner or later - all politics is a geo-politics. 
In the following section I look at evidence indicating that an incipient understanding of the earth as 'a gigantic machine for producing strata' may already have been present early in European modernity. But what became of this emergent sense of dwelling on a geologically turbulent planet is also significant - for it suggests that a willingness to think through the compositional depths and dynamics of the planet has by no means followed a smoothly ascending trajectory. And this tells us something of the history behind the prevalence of where do we belong or where are we questions over when are we?

\section{The Discovery (and Forgetting) of Strata}

Let us turn to another assemblage, one that also played a crucial role in the story of my own country. 'The true terrain of experience in the Modern Age is the ship's deck,' observes Peter Sloterdijk, 'no longer that 'earth' of which, as late as the twentieth century, the aging Edmund Husserl had sought to reassure himself, in a desperately conservative turn of phrase, as a ‘primal ark’ ... or ‘primal home’ (2014: 850-1). With the circumnavigation of the earth and the explorative-entrepreneurial voyages that followed, Sloterdijk argues, a two thousand year-old abstract conception of spherical globality gained an empirical underpinning. The world became physically as well as metaphysically one. Thought, however, was slow to keep up. Central European scholars in particular - Husserl's predecessors - stuck with their landlubbing provincialism: ‘Like every terran mind of the past, Kant, despite living in a seaport town, remained indebted

to the fixed location mentality' (Sloterdijk 2013: 89). Goethe and Hegel gestured towards the ocean, but for Sloterdijk, ultimately they too - like fellow 'grounded Europeans' recoiled from trans-global maritime adventure into the security of the solid earth (2013: $42-3,89-90)$. 
In Sloterdijk's take on globalization - like that of Carl Schmitt (2006[1950]) before him it is not merely the discovery of previously unknown continents nor ever-intensifying interconnectivity that defines the emergent modern 'world formation', but a novel European capacity to combine nautical prowess with the appropriation and mastery of the planet's terrestrial surfaces. However, this association of the sea with openness, fluidity and change and the terran element with fixity, stasis and foundationalism itself invites interrogation. For it is vital to recall that 'horizontal' expeditions were not the only mode of economic or onto-existential adventure at the threshold of European modernity. 'While Vasco da Gama, Columbus, and other explorers were finding new sea routes', notes John Nef, '...the Western peoples were again on the lookout for minerals' (1964: 70).

As maritime voyages pressed ever further outwards, mining operations followed seams ever more deeply beneath the earth's surface (Mumford, 2010 [1934]: 75). The very Central European savants chastened by Sloterdjk for their sedentarist `terranconservative' retreat from the oceanic outlook were often closely involved in this subterranean probing. Impelled both by geological curiosity and the shock of the 1755 Lisbon earthquake, Kant helped inaugurate the science of seismology; Goethe pitched enthusiastically into geological debates in between managing silver and copper mines; Hegel was a close follower of the pioneering paleontological work of Cuvier, an avid mineral collector, and assessor of the Jena Mineralogical Society (Ray, 2004; Kolb, 2008; Rudwick 2005: 26-7).

Whereas Sloterdijk cogently reminds us that motley crews of navigators, slavers, pirates and traders did much of the empirical work of assembling the new global spatial order (2013: 10, 112-5), so too should we heed Martin Rudwick's account, focused on the $18^{\text {th }}$ century, of practical contributions to the reconceptualization of the inner earth. 
Mining provided... not only ... empirical data on the dimension of depth in the earth's crust, but also - far more importantly - a distinctive way of thinking and even of seeing. Anyone involved in the mining industry, from ordinary miners right up the social scale to those who managed and administered mines, worked in a three-dimensional world of rock structures (2005: 84).

Even as oceanic exploration was adding and subtracting continents from the global imagination, traversal of the subsurface was generating evidence that greatly expanded the earth's temporal horizons (Toulmin and Goodfield, 1964: 150-1). Gradually, a clear sense emerged amongst Europe's earth-working practitioners and savants that the body of the earth was composed of an hierarchy of rock layers in which depth equated with age of formation. Though the basics of stratigraphic `superposition’ had been surmised in the $17^{\text {th }}$ century, it required a new way of conceiving of the earth as a having history of its own to shift from seeing rock strata as an invariant structural order to viewing them as expressions of a dynamic temporal sequencing (Rudwick, 2005: 97). Tied up with this emergent idea of 'geohistory' was a rapid unhinging of constraints on the lifetime of the planet. In little more than a human lifetime, estimates of the earth's age rocketed from a biblically sanctioned few millennia to hundreds of millions of years (Rudwick, 2005: 1246). For all he may have been spatially anchored in provincial Königsburg, Kant was on the cusp of this temporal unbounding. 'By 1750 men could contemplate a future lasting many thousands of years’, expound Toulmin and Goodfield, ‘but no one before Kant had talked so publicly and seriously of a past comprising "millions of years and centuries"” (1964: 133).

The shockwaves of geohistory arose not simply from the extension of time, however, but from the implications of the earth's dynamical formation. What an accumulating archive of fossilized remains of living creatures showed with increasing clarity was that past 
epochs of the earth had been populated by life-forms that had at some point ceased to exist (Rudwick, 2005: 242-4; Rossi, 1984: 3-6). And most of these epochs lacked fossil traces of humankind (Kant, 1993[1938]: 67). So while the intensifying horizontal traversal of the globe confronted Europeans with the vexing experience of peoples unlike themselves, vertical mobilization had - arguably - even more unsettling consequences, for it opened up huge vistas of earth history that were devoid of any human presence whatsoever. In the emergent geohistorical imagination, the combination of distinctive geological strata with specific communities of no longer extant life pointed towards successive transformations of the very earth itself: changes so momentous that they were capable of extinguishing entire worlds of creaturely life (Rudwick, 2008: 13; Toulmin and Goodfield, 1964: 151-2).

In the eyes of the theistically inclined, the prospect of 'worlds before Adam' - an earth history largely devoid of a being in God's image - raised anguishing questions about whom or for what purpose the Creator's handiwork had been intended (Rossi, 1984: 3031, 132-6). For more `enlightened’ minds, identifying and reaching a causal understanding of the 'revolutions of the earth' became one of the most intriguing and hotly contested questions of the era. But it seems that only a few of the most philosophically adventurous thinkers came close to countenancing the more existential issues raised by an earth that was periodically riven by life-annihilating upheavals. As Kant nervously inquired in his final work: `How many such revolutions (including, certainly, many ancient organic beings no longer alive on the surface of the earth) preceded the existence of man, and how many... are still in prospect, is hidden from our enquiring gaze (1993[1938]: 66-7). Hegel, with even more geophysical evidence at his disposal, contemplated not only 'tremendous revolutions belonging to a remote past', but even `profounder revolutions caused by alterations of the earth’s axis’ (cited in Kolb, 2008: 5). 
This is far cry from Sloterdijk's aspersions of a flinching from globality. It can hardly be said that Kant or Hegel chose stable terrestrial foundations over oceanic flux, for both philosophers engaged closely with explorations that were unsettling the solidity, fixity and given-ness of the terrestrial element every bit as much as tales from the ocean waves. While Sloterdijk - and the majority of other globalization theorists - views the traversal of the planet's surface as the impetus for the formation of a singular globe, it must be added that the geohistorians of the 'Modern Age' also played a major role in the constitution of integrated and unified earth. However, the differences between these constructions of globality may turn out to be at least as important as their commonalities. In the case of circumnavigation and its inheritors, it is buman agency that forges an inarticulate and impassive planetary body into a functional unity. In the geological vision, on the other hand, human observers bear witness to a dynamic earth that enacts its own oneness.

The full significance of an earth forged and shaped by its inherent dynamism is perhaps only becoming clear in the contemporary world. For a planet that stages its own revolutions is one whose very unity seems also to be self-compromised (Clark, 2016). It is an earth in which oneness or self-identity also conveys the potentiality of multiplicity or self-differentiation, as Kant, very early on, appears to have intuited. As he ruminated in Universal Natural History: 'millions of centuries will flow by, within which new worlds and world-orders form themselves one after another' (1981 [1755]: 154). It is in this sense that Sloterdijk is surely onto something important when he speaks of continental philosophers recoiling from ‘the new world situation’ (2014: 852). Though more than any global-oceanic unboundedness, it is the possible irruption of whole new lifeobliterating planetary orders that seems to have been the truly frightening prospect. Kant's deepest fear was not the roaming of the world by rogue Europeans or the encounter with foreign bodies. It was the potential of a monstrous earth to annihilate humankind altogether: the threat of 'natural revolutions' to render the universe's one 
and only moral being into just another fossil remain (Clark, 2011: 90-5). For in the absence of humanity, as Kant laments, 'the whole creation would be a mere waste, in vain, and without final purpose' (2005 [1790]: 219).

Perhaps it is not so much the ship's deck; the floating platform from which to gaze out upon the world's richness and diversity, but as Lewis Mumford proposed, the mineshaft - flush with resources but utterly devoid of life - that is the modernity's most haunting and revealing venue (2010 [1934]: 69 -70). It is from the encounter with geological strata and their ominous freight of petrified life, I have been suggesting, that modernising Europeans began to get a sense of the potentialities of the planet they inhabited. They seemed to have faced these prospects with varying degrees of curiosity and awe. But at the time, noone appeared willing to confront the full onto-existential implications of an earth capable of revolting against its own present condition and its all its current inhabitants.

Kant backed off from this chilling prospect, finding comfort in the idea that nature and the human subject were so tightly tethered and well matched that neither could really get along without the other. Hegel too, retrenched. Just as unwilling as Kant to countenance 'mind' being overcome by geological upheaval, he convinced himself that nature's formative convulsions belonged only to bygone phases of terrestrial and cosmic evolution — leaving the further ascent of Spirit untouchable by geo-cosmic force. The result was Hegel's imperious disavowal of geology: his pronouncement that the upheavals of the earth `are ... hypotheses in the historical field, and this point of view of a mere succession in time has no philosophical significance whatever' (cited in Kolb, 2008: 5).

As time went on, the upheavals of the earth and their expression in the planet's stratigraphic composition settled into the background of a world in rapid social 
transformation. Respected as the architecture of the solid earth, geological strata continued to be studied, inventoried, excavated - in the process shedding many of their earlier `revolutionary’ associations. Over the intervening two centuries, it has indeed been a human-induced unity - Sloterdijk’s ‘monogeism’ (2013: 6) - together with all its opportunities, risks, and pathologies - that has predominated in the western imagination of globality. In short, the boundaries human actors erect in the attempt to enable or constrain global mobilities have come to matter far more than the thresholds or junctures between states of the earth itself (Clark, 2013).

But even without the uptake of the Anthropocene thesis, strata have been edging their way back onto a broader agenda - in part, because of the very pervasiveness of their traversal and setting to work in the modern world. In this following section we look at the growing interest by social and political thinkers in the stratification of the earth, a concern impelled largely by conflicts and controversies attending the continued - and intensifying - dependence of the global economy on subterranean resources.

\section{From Vertical Territory to Geopower}

The interchange between surface and subsurface has radically intensified in the two centuries since Hegel's decisive geological retraction. In a strange twist, the efforts of a modernizing humanity to dodge the revolutions of the earth - to avoid the fate of fossilization - have relied deeply upon the utilization of fossilized hydrocarbons. Citing writer Italo Calvino, Gavin Bridge deftly captures both the time travelling dimension of this move and the implication of suddenly unleashing the potentiality of an entire stratum:

the 'rotating drill pushes in an instant from one millennium to the next as it cuts through the sedimentary rocks of the Pliocene, the Cretaceous, the 
'Triassic'. The result is that reserves of energy formed unimaginably slowly underground gush to the surface, the rate of release far exceeding the rate of formation. These immensely concentrated flows represent geological subsidies to the present day, a transfer of geological space and time that has underpinned the compression of time and space in modernity (2009: 48).

In this section I suggest that recent social and political thought around the subsurface brings into relief a kind of double movement or articulation. Firstly, theorists are coming to new understandings of specific modalities or techniques through which political power is being extended 'vertically' into the depths (and heights) of the earth. However, sustained and substantive engagement with these `volumes' can also open up a very different perspective on power: one that starts with the potency of geological strata and looks 'upward' to the usual stomping grounds of human experience and agency.

The turn to the role of verticality or volume in modern regimes of power and knowledge tends to set out from critical reconsideration of the ways in which the earth's surface has historically been partitioned and administered. In Elden's terms, the role of territory or bounded space gains its current significance when states have both the motivation and the technical ability to visualize, quantify and impose some degree of order over a specified terrain (2009: xxxvii). But these capacities are constantly shifting, Elden and other political theorists have noted, as new objects of political-administrative concern materialize and as new techniques are developed to target, envision and manipulate these objects (Elden, 2013b; Bridge, 2013). Both for reasons of securitization - new threats from the air or subversive underground activities - and because of the growing importance of subsurface mineral resources, this stretching and morphing of the territorial imperative has increasingly taken on pronounced 'vertical' dimensions (Weizman, 2002; Graham, 2004; Sloterdjik, 2009). 
Already, back in 2000, Bruce Braun made the case that territorial governance actually has a considerable history of concern with the subsurface. Using the example of $19^{\text {th }}$ century British Columbia to fill out Foucault's sketchy outlines of what it might mean for a state to concern itself with the qualities of its territory (2000: 12), Braun identifies an emergent political rationality in which the instruments of government are extended deep into geological substrata. Linking discourses of stratigraphical geology that emerged in the latter $18^{\text {th }}$ century with the global advance of extractive capitalism, he tracks the practices through which the mineral riches of the subsurface are drawn into wider stateorchestrated campaigns to optimize the wealth and vitality of spaces under their jurisdiction (2000: 22, 28-30).

Braun's account of the production of 'vertical territory' extends the logic of biopolitics in which the modern state produces the very conditions of life that it then seeks to regulate - beyond the domains of biological existence into the geologic depths of the earth. Elden, in his more recent and wide-ranging case for a vertical or volumetric understanding of territory, makes a similar point, stressing the common imperative of visualizing and ordering: 'While it is well known that biopolitics works on the basis of calculation and metrics geopolitics works with similar operative principles' (2013b: 49). Like Braun, Elden is not just concerned with the imagining of what lies beneath or above the planar surface, he is interested in how its specific qualities come to matter. Hence his concluding call to take 'the air and the subsoil; questions of land, terrain, territory (and) earth processes ... as the central terms at stake' (2013b: 49).

With its emphasis on the implementation of new techniques for rendering subsurfaces amenable to visualization, inventorying, securitization and manipulation, the turn to verticality inherits and reinforces the idea that territory is not simply given but is the historically contingent effect of a shifting production by particular governance 
imperatives, instruments and strategies (Graham, 2004; Elden, 2013b). But there is a tension here, a kind of deep, rumbling remainder to critical narratives of territorialization. For the more attention that is accorded to the actual qualities of the vertical domain, the more its own properties, processes and dynamics come to matter (see Dalby, 2013). And the more these potent, eventful, and definitely temporalized features are factored in, the harder it becomes to hold onto the idea that the object-world in question is an effect of the techno-political apparatuses through which it is disclosed.

The developmental side of extractive industry, especially in the global South, has likewise attracted critical attention, much of it focusing on uneven power relationships, conflicted governance and thwarted aspirations for autonomous growth (Bebbington, 2012). In this work too there are crucial junctures at which the qualities of the subsurface assert themselves - moments when the temporal, spatial and material specificities of the stratified earth appear irreducibly important. Mineral and energetic resources are distributed unevenly, some fields are small, other vast, some deep, others near-surface. As Bridge and others have noted, most mineral or hydrocarbon deposits have a restricted point of access that puts a premium on the process of 'securing the hole' and in this way serves to concentrate emergent pockets of governance and development. Once out of the ground, the mobilization of resources in order to (selectively) deliver them to sites of processing and end use further highlights properties such as density, volume, and viscosity (Bridge, 2009: 46-7).

In recent work by Timothy Mitchell (2011), this sense that the physical properties of a stratified earth are themselves a differential and constitutive force has been advanced as a way of understanding political formation themselves. Mitchell proposes that the very contours of $19^{\text {th }}$ and $20^{\text {th }}$ century democracy were shaped by socio-material orderings convened around use of fossilized hydrocarbons. In particular, he suggests that the sitespecific extraction and linear haulage of coal, together with its metabolic centrality to 
industrial production, provided opportunities for organized labour to intervene decisively at chokepoints in the energy system $(2011: 18-27)$. The $20^{\text {th }}$ century shift to oil - with its higher energetic intensity and increased portability - resulted in much more reticulated infrastructures and a corresponding disaggregation of workforces (2011: 36-9). The resulting diminishment of capacities to disrupt vital energetic flows, Mitchell contends, has had profound consequences for working class political potential: 'Unlike the movement of coal, the flow of oil could not be readily assembled into a machine that enabled large numbers of people to exercise novel forms of political power' (2011: 39).

We can follow the seams of subterranean ores and their socio-political flashpoints back still further: as some would have it, all the way to the genesis of oppositional working and capitalist classes. During the Central European mining boom of the late $15^{\text {th }}$ century, Fernand Braudel recounts, the escalating financial requirements of equipment needed to access ever deeper ores enabled rich merchants - as absentee investors - to gain control over mining and associated industries. 'Capitalism', intones Braudel, ‘entered a new and decisive stage' (1982: 321). In the process, previously independent mine workers found themselves dependent on owners of extractive capital. `And indeed this was when the word Arbeiter, worker, first appeared' (1982: 322). This is an argument anticipated by Lewis Mumford. 'More closely than any other industry', Mumford observes, ‘mining was bound up with the first development of modern capitalism', before adding that by the $16^{\text {th }}$ century it was also the occasion for 'the use of the strike as a weapon of defense, the bitter class war, and finally the extinction of the guilds' power' (2010 [1934]: 74-5).

Even more prescient is Mumford's formulation of ‘carboniferous capitalism': perhaps the first time a geological epoch or stratum is explicitly hitched to a social formation (2010 [1934]: 156-8). Like contemporary theorists of vertical territory, Mumford describes how capital probes, channels and re-organizes the subsurface. But then he turns this logic on its head - proposing that capitalist economic order and its 
accompanying cultural forms can be seen as an expression of the superfluity of available energy that comes from tapping into the earth's geological past. '(T)he sudden accession of capital in the form of these vast coal fields put mankind in a fever of exploitation...' writes Mumford: 'The animus of mining affected the entire economic and social organism' (2010 [1934]: 157-8).

Which brings us back to Bridge's earlier point that the availability of subterranean hydrocarbon deposits - millions of years of captured sunlight compressed and concentrated over eons - is a condition of the very mobility and interconnectivity that so much social thought takes to be definitive of globalization. So while it might indeed be argued that specific techno-political regimes and structures orchestrate the social interchange with different geological strata, precisely which direction the force and influence is moving in is difficult to determine. What Mumford seemed to glean, and what his later readers - including Georges Bataille and Deleuze and Guattari - developed further was the idea that matter-energy in all its excessiveness is as much a propellant and a provocation of organized social life as it is a resource to be used or an object of control.

Drawing explicitly on Deleuze and Foucault, but in ways that resonate with the energetic and extractive concerns of Mumford, Mitchell, and Bridge, Elizabeth Grosz (2012) has recently considered what it might mean for the very idea of the political to think through rather about the Earth. Grosz introduces the concept of 'geopower', which she suggests, along with its Foucauldian co-concept of 'biopower', ought to refer not simply to the practices by which objects or bodies come to be regulated by modern governing agencies but to the elemental forcefulness of the earth itself. In this regard, what human agency seeks to capture are the terrestrial and cosmic powers that are also what makes social existence, including our political formations, possible in the first place. 
What we understand as the history of politics - the regulations, actions and movements of individuals and collectives relative to other individuals and collectives - is possible only because geopower has already elaborated an encounter between forms of life and forms of the earth (2012: 975).

As Grosz would have it, most critical conceptualizations of politics fail to acknowledge this 'primordial interface' - this transacting with the generativity and potentiality of the material world - without which the political itself and all its transformative possibilities would be unsupported, unsustained, unpowered.

We have come some way from the idea that imperatives and techniques for governing life on the surface of the earth are currently going through a kind of volumetric extrusion. And yet it remains vitally important to understand how the modern partitioning of the earth's surface into interlocking, bounded and exclusionary spaces - in all its permutations - orchestrates the interchange between social and geological formations. In the following section, I try and hold onto these insights while also considering further what it might mean - in the context of human-induced changes and other components of the earth system - to approach the political through its geological subtending.

\section{Earth System Governance and its Others}

It hardly needs to be said that viewing the ground underfoot as conditional of social or political formations invites the charge of foundationalism. As Sloterdijk's deriding of European 'terran conservative' philosophy suggests, to take the quiddity of the earth as the baseline of human possibility is to summon critical censure. But such repudiations are informed by assumptions that grounding relations delimit or determine what is yet to 
be. Things tend to look very different when it is imagined that what lies beneath, before, beyond the social is a field of superfluity rather than simplicity or lack.

The idea of an excessive, ungrounding ground that Grosz taps into is a philosophical undercurrent that courses through Nietszche's world as a 'monster of energy' (1968[1901]), Bataille's energetically explosive cosmos (1991[1967]), and Deleuze and Guattari's stratifying/destratifying geo-body. In Deleuzoguattarian terms, the process of stratification might lock in the flux, free play, and intensities of a particular strain of matter-energy, but strata remain a locus of essential redundancy, the embodiment of a potentiality that always exceeds their current state (1987: 40). Teasing out this theme, Nick Land explains why thinking through strata affirms an excess of possibility rather than a circumscription or determination:

the stratification or stacking of organizational levels is the basic form of any possible surplus, the irreducible or final principle of 'real form': redundancy. Each stratum has its specific `negentropy’ or positive range of compositions, ‘selecting’ only a relatively narrow series of combinations from the stock of elements generated by its substrate (2011: 110-11).

Stratal relations, however, are more than a matter of each stratum feeding its yet-to-berealized possibilities onward and upward to whatever stratum comes next. As Deleuze and Guattari elaborate, if one side of a stratum faces ‘downward' to the strata that precede and subtend it, its other side is more 'outward' facing; a kind of surface that is exposed to and articulates with the wider world of uncongealed, dis-organized, not yet locked-in matter-energy (1987: 40-1). And it is this double articulation - a basal underpinning of substantial potentiality coupled with an outer exposure to the relatively free play of less-formatted elements - that affords strata their indispensable role in a dynamical, self-transformative universe. 
While we should not downplay disciplinary specificities, the current convergence between earth system science and stratigraphic geology has certain resonances with these more speculative philosophical engagements with strata. As we saw earlier, processes of stratal formation are increasingly being viewed in terms of their articulation with the systemic interplay of water, air and life at the earth's surface. It is it from these synergies between earth system thinking and stratigraphic geoscience that the idea of a singular or unitary planet - 'monogeism' we might say - is at once being reinforced and unsettled. Reinforced because earth system thinking is centred on the tight coupling of the planet's different components or subsystems - and foregrounds their worldwide or 'geosynchronous' traces in the earth's strata. But unsettled by the very same logic, by way of a composite picture that is increasingly one of a succession of dramatic transformations in the operating state of the earth system in its totality (Clark, 2016). So while Kant once speculated how `new worlds and world-orders form themselves one after another', today's Anthropocene' scientists now have the research base to surmise that 'the Earth seems to be less one planet, rather a number of different Earths that have succeeded each other in time, each with very different chemical, physical and biological states' (Zalasiewicz cited in Hamilton, 2014: 6). Only this time around, with a substantiated link between human agency and planetary dynamics, revolutions of the earth are a practical challenge - and a political problem.

The idea of putting in place forms of 'protection' for a range of earth subsystems was set out in an influential 2009 inter-disciplinary paper 'Planetary Boundaries: Exploring the Safe Operating Space for Humanity' - that links explicitly with the Anthropocene thesis (Rockström et al. 2009; see also Steffen et al, 2015). As Johan Rockström and colleagues propose, while thresholds themselves inhere in earth systems and are thus essentially non-negotiable, the process of identifying and agreeing upon 'safe' boundaries or guardrails around these thresholds is a profoundly political issue - calling for collective 
negotiation. Although as it stands, they lament, 'Current governance and management paradigms are often oblivious to or lack a mandate to act upon these planetary risks' (Rockström et al. 2009: 32). Or as other commentators remonstrate, there appear to be 'missing institutions' at the trans-national scale (Walker et al, 2009).

The perceived challenges of 'governing' earth systems invites the question of why it is, exactly, that as a species who has only ever inhabited a planet on which 'variability abounds ... at all scales', we appear so bereft of institutions oriented toward shifts in the physical systems upon which we rely. Even before the Anthropocene thesis had fully taken hold, political scientist Frank Biermann (2007) had been advancing the concept of 'earth system governance' as a way of highlighting political challenges posed by potential violation of planetary thresholds. From the outset, the focus has been on institutional reform and innovation - with particular emphasis on transnational cooperation. 'First and foremost, earth system transformation increases the interdependence of states' counsels Biermann (2014: 49), prompting recommendations for strengthening international treaty making and other trans-national initiatives. Aspirations to `continually evolving norms of global solidarity' are taken seriously enough to raise questions about the continued salience of full national sovereignty and to spark visions of `a whole new world organization whose task is to act in the interests of us all' (Biermann 2014: 40; Wijkman and Rockström 2011: 174).

Professing reservations about unbridled nation-state sovereignty in a world rife with the tensions and troubles of interconnectivity, however, is hardly the height of heterodoxy. As van Munster and Sylvest (2014) remind us, global interdependence and transnationalism have been recurrent themes in political discourse at least since the nuclear anxieties of the immediate post WWII period. Given that the traversing and unbinding of geological substrata are clearly central to the current anthropic aggravation of earth systems, the assumed 'missing institutions' of earth systems governance are 
conspicuous in their orientation to the inter-connected and co-present contours of the modern unified global spatial order. To put it another way, faced with a planet that is increasingly defined by discontinuity, non-self identity and multiplicity, what we seem to be being offered is a resounding return to Sloterdijk's 'discovered, interconnected and singularized earth'.

But after two hundred plus years of ducking the question, where do we begin to look for practices, techniques and institutions disposed to the challenge of negotiating strata? Dryzek and Stevenson make a related point, when they insist that ${ }^{`}(\mathrm{t})$ he democratisation of global earth system governance will need to draw on the lessons of experience, not simple application of normative reasoning' (2011: 1873). What then might be the earth system governance equivalent of the empirical underpinning of global oneness by circumnavigating seafarers in Sloterdijk's account? Or their counterpart to the 3-D grasp of rock structures accrued over generations of mining and quarrying in Rudwick's narrative?

Perhaps there are clues in remarks by Victor Galaz and colleagues that draw on observations of actual social-ecological systems undergoing acute change. '(D)ealing with incremental changes in "planetary boundaries" they propose:

require(s) coordinated action evolving around repeated interactions, predictability and execution by nations, regional organizations and international organizations. At the same time, dealing with ecological surprise and cascading effects of environmental change, requires multilevel and adhoc responses, where a high degree of flexibility and experimentation is allowed. Intriguingly enough, these two capacities seem to be difficult to maintain within the same institutional architecture (2012: 83). 
The acknowledgement here of 'flexibility and experimentation' in response to rapid systemic change is promising - even as the notion that actors ought to be allowed to respond in their chosen way hints ominously at a backdrop of prohibition. Although planet-scaled earth systemic shifts may not have occurred since the end of the Pleistocene ice ages some 10-11,000 years ago, different human collectivities have a wealth of experience acquired through enduring threshold transitions at scales other than the planetary. Which raises searching questions about what has become of this experience. For, as Galaz et al allude, we need to ask just how compatible the dominant institutional forms of a globalizing modernity have been with the world of techniques, strategies and practices that evolved to deal with long-term bio-geo-physical variability (see Clark 2008).

In this regard, we should heed Mike Davis's (2001) evidence of the devastating impact of incorporation of the agrarian tropics in the newly globalizing economy of the latter $19^{\text {th }}$ century: his account of how economic ‘modernization’ decimated peasantries by undermining long-term and hard won adaptations to the climatic oscillations of the monsoonal latitudes. Indeed, environmental anthropologists, ethno-scientists, grassroots activists and a great many 'traditional' practitioners and scholars would be unsurprised at Galaz et al's revelation that 'adhoc' adaptations to environmental variability rarely co-exist happily with ‘higher order’ state or interstate imperatives. In other words, what earth system governance theorists may be over-looking is that the 'missing institutions' for dealing with the dynamism of ecological and geo-climatic systems have been there all along - which is to say suppressed and marginalised rather than awaiting invention. So too is there a need to consider - where they have not simply been 'governed' out of existence - how techniques and strategies oriented to the earth's longue durée have suffered from exposure to the corroding rush of subterranean energy; that is, from the very excesses of geopower that have made today's version of global interconnectivity conceivable. 
If we are to think in terms of a politics of strata, earth system 'governance' is not a matter of choosing - or mediating - between place-based and trans-local options. What appears 'local' may well be temporally 'unbound', which is to say oriented to an earth that does its own mobilizing - or in Deleuze and Guattari’s terms, ‘carries out a movement of deterritorialization on the spot' (1994: 85). Or as we might say, destratification on the spot. There are collectivities who have already been holding a shifting ground for centuries, millennia or even tens of millennia (see Spivak, 1999: 402). Before we even begin to dream of the Anthropocene, these latter spans take us through the last glacial maximum and into the current interglacial: concatenations of events that would certainly require adhoc responses but also demand that such innovations were worked into enduring architectures. And in this sense, would-be earth system governors might do well keep in mind the words of Australian Aboriginal actor-storyteller Trevor Jamieson, who when confronted with the estimated 25,000 year contamination of his tribal lands caused by nuclear weapons testing, calmly responds 'We can wait' (cited in Gilbert 2013: 206).

\section{Negotiating Strata}

In this paper I have been proposing a kind of double articulation as a way to make sense of the becoming political of the earth's geological strata and its strata-generating processes. This entails looking downward from within the social and political formations we have constructed on the earth's surface and beneath its skies. At the same time, it summons us to look upward, as it were, from the perspective of a structured and constantly restructuring earth. With regard to the question of how we make use of the earth's resources and how we are exposed to its agitations, it matters very much where we are located on the globe's heavily socio-politically coded and structured surface. But I 
have been suggesting that the question of when we are positioned - at what moment in geohistory, at what point in the trajectory of an earth system, on what exposed strata - also matters profoundly.

Even when not conspicuously digging into the soil or its substrate, every individual, group or social formation is positioned on or across the earth's strata. To inhabit a stratum is also to face outward, to be exposed to those more evanescent and unbounded forces that have not yet settled into distinct compositional layers. This puts all human life - all organismic life - in the midst of stratal formation and deformation. It positions us in that slender province where the immense energy of incoming solar radiation converges with the upwelling forces of the earth's radiative core, a critical zone where volatile and erosive forces are ceaselessly weathering older exposed strata and sedimenting them into fresh layers. And this means that all human habitation of the earth, even when it doesn't entail circumnavigation or other excursions, is a kind of journey - a passage through the multi-scalar rhythms, singularities and thresholds of a planetary surface in motion.

The question that arises from trying to think the social and the political stratigraphically, then, is not so much whether we - or at least the most heavy-handed of us - ought to abstain from geological agency. It is how we, collectively and heterogeneously, might negotiate more carefully, more judiciously, more generatively with strata. In general terms, the engagements with strata at the heart of western modernity have been frenzied, crude, and profoundly corrosive of a world of other ways of traversing and channeling the productions of the earth. As Deleuze and Guattari (1987: 502-3) remind us, and as earth system governance theorists seem to have more-or-less gleaned, all traversal of strata is hazardous. Working with strata is uncertain and fraught because it involves actualizing some of the potential of forces that will always exceed our understanding and utilization. In the words of Kai Bosworth: 
Ecological or geologic dangers, threats or catastrophes impinge upon us not due to a lack of understanding or thought by humans, but due to a surplus of potentiality exhibited by the Earth. In order for this surplus to exist, it must not be essentially connected to every other part of the earth system (2013: fn 4).

Putting this surplus to work remains risky too because the environments into which new techniques, productions and assemblages are introduced are themselves inconstant reinventing their own criteria of acceptability as they goes along. Reflection, deliberation and dialogue in this context are crucial - but also inadequate. For there is much that can only be learnt by way of material intervention, through iteration, trial and error. Who gets to experiment, where and when, is a key consideration. So too is the question of how to deal with experiments that fall short, go awry or succeed too well (Clark, 2014). If the earth system is indeed approaching one or more transitional points, then enhancing and proliferating this experimental capacity looks to be a matter of urgency. Still more urgent is the need to preserve as much as we can of the matter, the flows, the reservoirs with which we will be doing the experimenting.

At any moment we only touch the exposed faces of some of the earth's strata - while other strata remain out of reach. Any elaboration or variation on the theme of a politics of strata is unlikely to involve straightforward expansion the domain of the political. If attempts to rearticulate social relations with the geologic substrate might embody new possibilities for collective action, they also disclose real limits of human agency (Clark, 2013). Sooner or later, any politics oriented toward strata will come up against what Claire Colebrook refers to as the 'monstrously impolitic’ (2011:11) or what Grosz describes as ‘cosmological imponderables’ (2008: 23): elemental forces whose reach stretches far beyond any human collective. In a certain sense, then, all politics might be 
seen as a kind of trans-acting between the exposed surfaces to which we can make some difference and those deeper forces and formations that will stubbornly cleave to their own agenda. Which means that there are real limits to our ability to 'govern' the rhythms and singularities of earth systems.

\section{References}

Aitchison L (1960) A History of Metals, Volume 1. London: MacDonald \& Evans.

Bataille G (1991) The Accursed Share: Volume I. New York: Zone.

Bebbington A (2012) Underground political ecologies. Geoforum 43: 1152-1162.

Biermann F (2007) 'Earth system governance' as a crosscutting theme of global change research. Global Environmental Change 17: 326-337.

Biermann F (2014) Earth System Governance: World Politics in the Anthropocene. Cambridge MA.: MIT Press.

Bosworth K (2013) Notes towards a geological uprising by way of a dark feminism.

Society and Space. Available at: http://societyandspace.com/reviews/reviewsarchive/woodard-2013-kai-bosworth/ (accessed 27 January 2015)

Braudel F (1982) The Wheels of Commerce. London: Collins. 
Braun B (2000) Producing vertical territory: Geology and governmentality in late Victorian Canada. Cultural Geographies 7 (7): 7-46.

Bridge G (2009) The Hole world: Scales and spaces of extraction New Geographies 2: 4348.

Bridge G (2013) Territory, now in 3D! Political Geography 34: 55-57.

Clark N (2008) Aboriginal cosmopolitanism. International Journal of Urban and Regional Studies 32 (3): 737-744.

Clark N (2011) Inbuman Nature: Sociable Life on a Dynamic Planet. London: Sage.

Clark N (2013) Geopolitics at the threshold. Political Geography 37: 48-50.

Clark N (2014) Geo-politics and the disaster of the Anthropocene. The Sociological Review 62:S1: 19-37.

Clark N (2016 forthcoming) Anthropocene incitements: Toward a politics and ethics of ex-orbitant planetarity. In van Munster R and Sylvest C (eds) The Politics of Globality since 1945: Assembling the Planet. Abingdon, Oxon: Routledge.

Colebrook C (2011) Matter without bodies. Derrida Today 4: 1-20.

Cushman G (2013) Guano and the Opening of the Pacific World: A Global Ecological History.

Cambridge: Cambridge University Press.

Dalby S (2013) The Geopolitics of Climate Change. Political Geography 37: 38-47. 
Davis M (2001) Late Victorian Holocausts: El Nino Famines and the Making of the Third World. London: Verso.

Deleuze G and Guattari F (1987) A Thousand Plateaus: Capitalism and Schizophrenia. Minneapolis: University of Minnesota Press.

Deleuze G and Guattari F (1994) What is Philosophy? London: Verso.

DeLanda M (1997) A Thousand Years of Nonlinear History. New York: Swerve

DeLanda M (2002) Intensive Science and Virtual Philosophy. London: Continuum.

Dryzek J and Stevenson H (2011) Global democracy and earth system governance. Ecological Economics 70: 1865-1874

Elden S (2009) Terror and Territory: The Spatial Extent of Sovereignty. Minneapolis: University of Minnesota Press.

Elden S (2013a) The Birth of Territory. Chicago: University of Chicago Press.

Elden S (2013b) Secure the volume: vertical geopolitics and the depth of power. Political Geography 34: 35-51

Galaz V, Biermann, F, Crona, B et al (2012) 'Planetary Boundaries’ - exploring the challenges for global environmental governance. Current Opinion in Environmental Sustainability 4: 80-7 
Gilbert H (2013) Indigeneity, time and the cosmopolitics of postcolonial belonging in the Atomic Age. Interventions 15 (2): 195-210.

Graham S (2004) Vertical geopolitics: Baghdad and after. Antipode 36 (1): 12-23.

Grosz E (2008) Chaos, Territory, Art: Deleuze and the framing of the Earth, Durham, NC:

Duke University Press.

Grosz E (2012) Geopower. Environment and Planning D: Society \& Space 30(6) 973-975.

Hamilton C (2014) Can Humans Survive the Anthropocene? Available at:

http://clivehamilton.com/can-humans-survive-the-anthropocene/ (accessed 4 October, 2015)

Kant I (1981[1755]) Universal Natural History and Theory of the Heavens. Edinburgh: Scottish Academic Press.

Kant I (1993 [1938]) Opus Postumum. Cambridge: Cambridge University Press.

Kant I (1996 [1795])Toward Perpetual Peace. In M Gregor (ed) The Cambridge Edition of the Works of Immanuel Kant: Practical Philosophy, Cambridge: Cambridge University Press.

Kant I (2005 [1790]) Critique of Judgement. Mineola, NY: Dover Publications.

Kolb D (2008) Darwin rocks Hegel: does nature have a history? Bulletin of the Hegel Society of Great Britain 57: 97-117.

Land N (2011) Fanged Noumena: Collected Writings 1987 - 2007. Falmouth: Urbanomic. 
Lewis S and Maslin M (2015) Defining the Anthropocene. Nature 519: 171-9.

Mitchell T (2011) Carbon Democracy: Political Power in the Age of Oil. London: Verso.

Mumford L (2010[1934]) Technics \& Civilization. Chicago: University of Chicago Press.

van Munster R and Sylvest C (2014) Reclaiming nuclear politics? Nuclear realism, the Hbomb and globality. Security Dialogue 45 (6): 530-547.

Nef J (1964) The Conquest of the Material World. Cleveland: Meridean Books.

Nietszche F (1968 [1901]) The Will to Power. New York: Vintage Books.

Ray G (2004) Reading the Lisbon Earthquake: Adorno, Lyotard, and the contemporary sublime. Yale Journal of Criticism, 17 (1) 1-18

Rockström J, Steffen W, Noone K et al (2009) Planetary boundaries: exploring the safe operating space for humanity. Ecology and Society 14 (2): 32

Rogoff I (2000) Terra Infirma: Geography's Visual Culture. London: Routledge.

Rossi P (1984) The Dark Abyss of Time. Chicago: University of Chicago Press

Rudwick M (2005) Bursting the Limits of Time: The Reconstruction of Geohistory in the Age of Revolution. Chicago: University of Chicago Press.

Rudwick M (2008) Worlds before Adam: The Reconstruction of Geobistory in the Age of Reform. 
Chicago: University of Chicago Press.

Serres M (1995) The Natural Contract. Ann Arbor: University of Michigan Press.

Sloterdijk, P (2009) Airquakes. Environment and Planning D: Society and Space 27: 41-57.

Sloterdijk P (2013) In the World Interior of Capitalism. Cambridge: Polity.

Sloterdijk P (2014) Spheres 2: Globes - Macrospherology, South Pasadena, CA: Semiotext(e).

Spivak, G C (1999) A Critique of Postcolonial Reason: Toward a History of the V anishing Present. Cambridge MA: Harvard University Press.

Steffen W, Sanderson A, Tyson P et al (2004) Global Change and the Earth System: A Planet Under Pressure. Berlin: Springer-Verlag.

Steffen W, Richardson K, Rockström J et al (2015) Planetary boundaries: Guiding human development on a changing planet. Science 347 (6223) 1259855-1 - 10.

Toulmin S and Goodfield J (1965) The Discovery of Time. Chicago and London: University of Chicago Press.

Walker B, Barrett S, Polasky S et al (2009) Looming global-scale failures and missing institutions. Science 325: 1345-6.

Weizman E (2002) The Politics of verticality. Open Democracy. Available at: http://www.opendemocracy.net/ecology-politicsverticality/article_801.jsp (accessed 31 January 2015) 
Wijkman A and Rockström J (2011) Bankrupting Nature: Denying Our Planetary Boundaries. London: Earthscan.

Zalasiewicz J (2008) The Earth after Us. Oxford: Oxford University Press.

Zalasiewicz J, Williams M, Smith A et al (2008) Are we now living in the Anthropocene? GSA Today 18: 4-8.

Zalasiewicz J, Steffen W, Leinfelder R et al (2016 forthcoming). Petrifying Earth process. Theory, Culture \& Society. 